\title{
STOCK PERFORMANCE COMPARISON BETWEEN GREEN INNOVATION SHARIA COMPANIES AND GREEN INNOVATION NON-SHARIA COMPANIES: EVIDENCE FROM INDONESIA STOCK EXCHANGE
}

\author{
Yadi Nurhayadi, N. Wijiharjono, Ummu S. Al-Azizah ${ }^{1}$, Satirenjit K. Johl, A. Shamim², and Prof \\ Shireenjit. Kaur ${ }^{3}$ \\ ${ }^{1}$ Faculty of Economic and Business - University of Muhammadiyah Prof. Dr. HAMKA (UHAMKA) \\ ${ }^{2}$ Depatment of Management and Humanities - University of Technology Petronas (UTP) \\ ${ }^{3}$ Department of Accounting, Finance and Economics, Griffith University
}

\begin{abstract}
This Research is about comparison between sharia companies and non-sharia companies in the stock market. Several previous studies have shown that in the stock market, the stock performance of sharia companies is better to that of non-sharia companies. Then this research increases the qualification of the companies to become companies that have implemented green innovation technology. This qualification is applied to companies listed in the Sri-Kehati index on the Indonesia Stock Exchange. Through bivariate and multivariate analysis, the results showed that the stock performance of non-sharia companies was better than those of sharia companies. Bivariate analysis show that the positive gradient of non-sharia trendline (168.37) is bigger than sharia trendline (11.633). The coefficient of determination between non-sharia stocks and Sri-Kehati index (86.41\%) is bigger than between sharia stocks and Sri-Kehati index (26.46\%). Multivariate analysis obtained a multiple linear regression equation of $\hat{y}=117.187+0.0081 x_{1}+0.014397 x_{2}$. This equation shows that the variable coefficient of the value of sharia stocks is smaller than the coefficient of the variable value of non-sharia stocks. These facts are based on research on Sri-Kehati index data from 2016 to 2019. The results of this study indicate that investors prefer to invest in shares in non-sharia companies than in sharia companies. The results also indicate that increasing the qualifications of a sharia company to become a company that applies green innovation technology will not necessarily increase its share value. Is upgrading the qualification of a sharia company to a sharia company that applies green innovation technology a mistake? Meanwhile, Indonesia is a country with the largest Muslim population in the world.
\end{abstract}

Keywords: sharia companies, non-sharia companies, green innovation technology, bivariate and multivariate analysis.

\section{Introduction}

In the recent years, the Islamic finances are spread enormously around the world. Financial universe including investment and financing activities are based on sharia compliant. With the screening criteria, Islamic equity index providers was classify as a sharia compliant or noncompliant for the company, in order to easy processes. Therefore, with the sharia screening process, financial activities (example investment) can be differentiates whether permissible or non-permissible. To conclude, with the sharia screening status of the activities, it can be defined the Islamic companies and businesses. Moreover, sharia compliant companies also practice CSR as it is integral to fulfill religious commitments. 
Stock prices are one of the important topics in financial economics in terms of determinant identifications. The factors such as interest rate, inflation rate, exchange rate, money supply, domestic production, etc. were recent and commonly review by the researchers. Some example of the studies which included the International crude oil price as one of determinants of stock price have tried to verify by testing co-integration approach with the daily data between 2006 and 2018 (Singhal et al., 2019). Another studies linked to stock prices such as Tang \& Yao (2018), Akbar et al (2019), and Li et al (2018).

Previous studies have examined the comparison of stock performance between Islamic and conventional stock prices. For example, the inspiration for this research is a series of studies by Nurhayadi and friends. Research has been conducted by (Nurhayadi \& Wijiharjono, 2018) shows that a high correlation between the Islamic market and conventional markets. They assume the Jakarta Islamic Index (JII) and the Indonesia Sharia Stock Index (ISSI) as a representation of the sharia market and the Jakarta Composite Index (IHSG) and the Jakarta Stock Exchange Liquid (LQ45) as a representation of the conventional market. Subsequent research by (Nurhayadi, Y; Rito; Azizah, 2018) revealed that the assumption that the IHSG and LQ45 represent conventional markets, because the IHSG and LQ45 are also dominant Islamic issuers. Their research specifically found that Islamic stocks are better than conventional stocks. This finding is reinforced by the research of (Nurhayadi et al., 2019) that on the Indonesia Stock Exchange, Islamic stocks perform better than conventional stocks.

Some studies above shows that the performance of Islamic stock prices has been employed the better performance compared to conventional. Thus, the main purposes of our research are to examine (i) whether Islamic stock markets' have a better performance rather than conventional counterparts, and (ii) the extent of how green innovation technology implemented by the companies will increase the stock prices' market.

Several contributions from the current study offers to the literature. Firstly, focusing on the distinctions between Islamic stock prices and conventional one and the correlations to the Sri Kehati in addition, the study provides evidence of using green innovation, there is an improvement of financial performance of the firms and increase the stock prices. Indeed, some investors (such as Islamic investors) prefer to make a green investment in their portfolios. Particularly, the co-movement between variables is examines at different frequencies and overtime, therefore, providing better insights about the relationship.

This study uses the companies which are listed in the SRI-KEHATI index as a research objects. This index are launched and managed in collaboration with the Indonesian Biodiversity Foundation (KEHATI Foundation) and as one of the indices on the Indonesia Stock Exchange. The selected companies are standardized that apply the principle of Sustainability Responsible Investment (SRI), and also integrated with the Environmental, Social and Governance (ESG). The investment references for the investors which are emphasize ESG issues in Indonesian capital market might to use the SRI-KEHATI index. However, our study's contributions includes. Firstly, to investigate the impact of conventional and Islamic stock prices of the green indexes, we apply statistical analysis of uncertainty for stock indexes (Jawadi et al., 2019). Second, with the good understanding about the green innovation implemented by the Islamic companies, the investors' preferences on investment will be changes.

\section{Theoretical Framework}

Behavioral finance in enormous literature tried to analyze the investors' behavior in their investment management (Chen et al., 2019). Previous research are has been done related to personality preferences on investment, such as Polzin et al (2018). The study mention that between entrepreneurs and investors are should be matching on the purposes to achieve their financial goals. In terms of perception differentiate in between investors and entrepreneurs, there are in such areas, like evaluation, risk and risk management. Every counterpart are should have understanding what the essential for themselves to find a good match. Moreover, this study showed that the perception of risk was an existing problem. Therefore, the increasing number of market transparency and creating a mutual understanding on the process of investment should be taken as an important part.

In the perspective of psychological traits, Akhtar \& Das (2020) mentioned on their study that financial risk tolerance (FRT) as a psychological biases, and overconfidence in financial matter are related to the investors' investment performance. The mixed method has been used to collect 983 responses from the individual investors through the questionnaire in order to assess their psychological traits, personality traits, and investment performance. With the limitation on this study, such as pre-testing questionnaire has not been taken and limited sampling, the result of this study was amazed. It was revealed that between personality traits and investment performance can be mediated by the psychological traits. In line with this, Akhtar et al (2018) with different number of responses, the study suggest that there is a positive correlation between social influence and extraversion-perceived performance of investment. Meanwhile, it was negative impacted between agreeability-perceived investments' performance. Then, it can be argued from these studies that psychological traits will influence investors' investment decision and diversification. 
Another study, as an opposite with mentioned above, that individual investment decisions was not influenced by the heuristic theory and would not perceive the market efficiency (Shah et al., 2018). The research hypotheses examined by using regression analysis to determine whether between investment decisions and market efficiency might be affected by the heuristic biases. However, this paper provided the insight empirically that overconfidence (an example of heuristic bias) have markedly negative impact on the investment decisions. Nonetheless, it is necessary for investors to focus on an investment strategy in order to control their mental mistakes as part of heuristic biases.

With the certain of sharia conditions, Islamic stock share are similar with the conventional ones. Nevertheless, the firm performance are differs in terms of product type, location, linkage to crises, size and efficiency. Investors, due to some factors related, are targeting whether they can realize higher return with the investment diversification and take the opportunity to share risk among markets.

The budgeting of capital and stock markets are mainly depending on the level of development, performance and risk based on the modern financial theory. In addition, investors should be considers related with the informational capital market efficiency. For example, they should be able to easily determine the risk of level and profitability of their investments. Therefore, there is no overvalued or undervalued issue. Based on the previous study by Alam et al (2016), it was revealed that, compared to conventional one, Islamic stock indexes are more volatile and are not immune in total with the global financial crises. And as regards of the efficient market information, the result shows that the Islamic stock prices are more efficient than the conventional stock prices. Thus, it can be attracted more investors to have an investment portfolio involved the Islamic stock in the capital market.

In comparison with the conventional stock prices, the Islamic stock returns can be predicted and improved with the economic policy uncertainty, oil prices, and investors' sentiment (Ftiti \& Hadhri, 2019). Some studies such as (Ali et al., 2018) mentioned that Islamic stock markets' higher than their conventional counterparts in part of speculative activity. The data assessed with comparison between 12 Islamic and conventional stock markets counterparts by the analysis of multi-fractal de-trended fluctuation (MF-DFA). The result of this study implied that due to Islamic stock markets are new and naturally peculiar, it seems more efficient due to sharia compliant laws and good governance and also some of disclosure mechanism.

Regarding to the green innovation technology, there are many terminologies regardless the green innovation (i.e., eco-innovation, sustainable innovation, environmental innovation, etc). According to Varadarajan (2017), there was a limitations related the definition of green innovation were offered by the literature and identification. The study mentioned that the term of green innovation impores the company's competitioness regarding to the innovation and negative impact of environmetal reduction. He et al (2019) and Shahzad et al (2019, 2020). Moreover, thr innovation of green have an important part for industry moving towards sustainable production, and the evolution of sustainable manufacturing initiatives has been facilitated by green innovation.

Many surveys conducted in several contexts suggested that green innovation and financial performance are positively correlated. For instance, Xue \& Boadu (2019) studied the penetration of green innovation on firm performance, through questionnaire survey from 253 companies in China and using hierarchical linear modeling (HLM), the study revealed that there was a robust positive effect between green innovation and firm financial performance. It can be concluded that there is an integrating effects related absorptive capacity, managerial environmental concern, green innovation and firm performance dimensions. Zhang et al (2019) identified that manufacturing firms in China implemented the green patenting and successes improving the firm performance. And it was begin since the government provided the legislative support for the green industry.

On the other hand, Lin et al (2019) collected the data for 6 years with around 163 automotive firms, and measuring with the dynamic panel data system. The result of this study mentioned that Green Innovation Strategies (GIS) has negative effect for the Corporate Financial Performance (CFP). The authors also showed that smaller firms have the higher green innovation investments return than larger-sized firms, this phenomena indicate that these small firms gain more opportunity in order to accessing better resources. In addition, the previous study analyzed the Standard \& Poor's 500 listed companies in between 1996 - 2016, they found that too much concentration on green innovation has a negative influence for both accounting and stock market performance Przychodzen et al (2019).

Ye \& Cheng (2019) investigates the direct effect of green technology innovation as a "win-win" solution between environmental performance and economic performance. The study has been done in Chine from 30 provinces during the year 2006 and 2016. With included green technology innovation, governmental of governance, economic basis and also financial development, system and integrity of culture on green technology innovation. Moreover, as acontrol variable, GDP included for the current study, and the resul shows that environmental regulation can significantly promote the green innovation in terms of innovation efficiency.

Knowledge management $(\mathrm{KM})$ in green innovation was an important part for the corporate sustainable development (CSD) activities. However, Abbas (2019) in his study mentioned that knowledge management has a positive significant impact for both green innovation and also corporate sustainable development. The data was 
collected from lower, middle and upper level managers of small, medium and large-sized manufacturing and firms. With the exception of knowledge, the dimensional analysis indicated for the creation and acquisition. And with further information, knowledge management was an equal important for all level of corporation and services firm.

\section{Data and Variables \\ 3.1 Data}

All the data are from Indonesia Stock Exchange activities. The data in this study include:

1. The share value of 8 sharia issuers at the end of each month which are consistently listed on the Sri-Kehati index and Jakarta Islamic Index (JII) for 3 years (36 months) from August 2016 to July 2019. The eight Islamic issuers consist of: ASII (Astra International Tbk.), BSDE (Bumi Serpong Damai Tbk.), INDF (Indofood Sukses Makmur Tbk.), KLBF (Kalbe Farma Tbk.), TLKM (Telekomunikasi Indonesia (Persero) Tbk.), UNTR (United Tractors Tbk.), UNVR (Unilever Indonesia Tbk.), and WIKA (Wijaya Karya (Persero) Tbk.).

2. The share value of 4 non-sharia issuers at the end of each month which are consistently listed on the SriKehati index for 3 years (36 months) from August 2016 to July 2019. The four non-sharia issuers are: BBCA (Bank Central Asia Tbk.), BBNI (Bank Negara Indonesia (Persero) Tbk.), BBRI (Bank Rakyat Indonesia (Persero) Tbk.), and BMRI (Bank Mandiri (Persero) Tbk.).

3. The Sri-Kehati index value at the close of each month's end is consistently listed in the Sri-Kehati index for 3 years (36 months) from August 2016 to July 2019.

\subsection{Variables}

There are six scenarios for this research.

1. The trendline of sharia stocks: $x=$ month, $y=$ the average value of sharia stocks, bivariate analysis.

2. The trendline of non-sharia stocks: $x=$ month, $y=$ the average value of non-sharia stocks, bivariate analysis.

3. The trendline of Sri-Kehati index: $x=$ month, $y=$ the Sri-Kehati index, bivariate analysis.

4. The linear regression: $x=$ the average value of sharia stocks, $y=$ the Sri-Kehati index, bivariate analysis.

5. The linear regression: $x=$ the average value of non-sharia stocks, $y=$ the Sri-Kehati index, bivariate analysis.

6. The multiple linear regression: $x_{1}=$ the average value of sharia stocks, $x_{2}=$ the average value of non-sharia stocks, $y=$ the Sri-Kehati index, multivariate analysis.

\section{Methods}

Bivariate and multivariate analysis has been taken for this study. The analysis is based on equations that developed by Walpole, Ronald E; Myers, Raymodh H; Myers, Sharon L; Ye (2013).

In using bivariate analysis, independent variable $(x)$ and dependent variable $(\hat{y})$ estimated or fitted regression line that is given by

$\hat{y}=b_{0}+b_{1} x$

The fitted line is an estimate of the true regression line.

The plotted of a scatter diagram for the $\mathrm{X}$ and $\mathrm{Y}$ data mentioned that there is a linear correlation between two variables.

Given the sample $\left\{\left(x_{\mathrm{i}}, y_{\mathrm{i}}\right) ; i=1,2, \ldots, n\right\}$, the least squares estimates $b_{0}$ and $b_{1}$ with formulas,

$$
b_{1}=\frac{n \sum_{i=1}^{n} x_{i} y_{i}-\left(\sum_{i=1}^{n} x_{i}\right)\left(\sum_{i=1}^{n} y_{i}\right)}{n \sum_{i=1}^{n} x_{i}^{2}-\left(\sum_{i=1}^{n} x_{i}\right)^{2}}, b_{0}=\bar{y}-b_{1} \bar{x}
$$

then $\hat{y}=b_{0}+b_{1} x$ is defined.

Correlation between $x$ and $y$ is calculated by the Pearson product-moment correlation coefficient, $r$.

$$
r=\frac{S_{x y}}{\sqrt{S_{x x} S_{y y}}}
$$

where 
$S_{x x}=\sum_{i=1}^{n} x_{i}^{2}-\frac{\left(\sum_{i=1}^{n} x_{i}\right)^{2}}{n}, S_{y y}=\sum_{i=1}^{n} y_{i}^{2}-\frac{\left(\sum_{i=1}^{n} y_{i}\right)^{2}}{n}, S_{x y}=\sum_{i=1}^{n} x_{i} y_{i}-\frac{\left(\sum_{i=1}^{n} x_{i}\right)\left(\sum_{i=1}^{n} y_{i}\right)}{n}$

The values of $r$ are $-1 \leq r \leq+1$. If the value of $r$ is close to +1 , it means that between $x$ and $y$ has strong and positive correlation. If $r$ is close to -1 , it means that between $x$ and $y$ has strong and negative correlation.

Then $r^{2}$, which is usually referred to as the sample coefficient of determination. The $r^{2}$ expresses the proportion of the total variation in the values of the variable $y$ that can be accounted for or explained by a linear relationship with the values of the random variable $x$. Thus, a correlation of 0.6 means that 0.36 , or $36 \%$, of the total variation of the values of $y$ in our sample is accounted for by a linear relationship with values of $x$.

Meanwhile, in using multivariate analysis, the independent variables are $x_{1}$ and $x_{2}$ respectively, and the dependent variable is $y$. Then the estimated or fitted regression line is given by $\hat{y}=b_{0}+b_{1} x_{1}+b_{2} x_{2}$

Given the sample $\left\{\left(x_{1}, x_{2}, y\right) ; i=1,2, . ., \mathrm{n}\right\}$, the least squares estimates $b_{0}, b_{1}, b_{2}$ by solving normal estimation equations

$n b_{0}+b_{1} \sum_{i=1}^{n} x_{1 i}+b_{2} \sum_{i=1}^{n} x_{2 i}=\sum_{i=1}^{n} y_{i}$

$b_{0} \sum_{i=1}^{n} x_{1 i}+b_{1} \sum_{i=1}^{n} x_{1 i}^{2}+b_{2} \sum_{i=1}^{n} x_{1 i} x_{2 i}=\sum_{i=1}^{n} x_{1 i} y_{i}$,

$b_{0} \sum_{i=1}^{n} x_{2 i}+b_{1} \sum_{i=1}^{n} x_{1 i} x_{2 i}+b_{2} \sum_{i=1}^{n} x_{2 i}^{2}=\sum_{i=1}^{n} x_{2 i} y_{i}$

The sample coefficient of determination $\left(r^{2}\right)$ is given by

$$
r^{2}=\frac{\left[b_{0} \sum_{i=1}^{n} y_{i}+b_{1} \sum_{i=0}^{n} x_{1 i} y_{i}+b_{2} \sum_{i=0}^{n} x_{2 i} y_{i}-\left(\sum_{i=1}^{n} y_{i}\right)^{2} / n\right]}{\sum_{i=1}^{n} y_{i}{ }^{2}-\frac{\left(\sum_{i=1}^{n} y_{i}\right)^{2}}{n}}
$$

and the sample coefficient of correlation

$$
r=\sqrt{r^{2}}
$$

\section{Results}

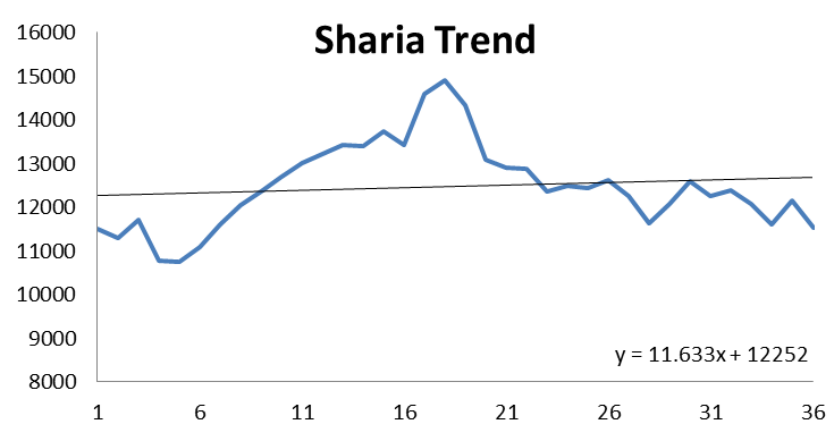

Picture-1. The average value of sharia stocks trend. 


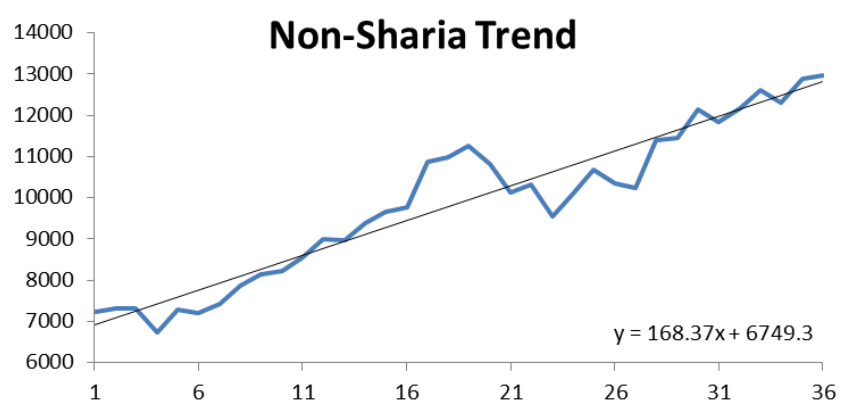

Picture-2. The average value of non-sharia stocks trend.

The trend of sharia stocks average value is positive, with gradient of 11.633 . The trend of non-sharia stocks average value is positive too, with gradient of 168.37 . These indicate that in general stock values are increase. This condition is consistent with the Sri-Kehati index trend. The gradient of non-sharia stocks is bigger than the gradient of sharia stocks. The stock value of non-sharia trend is better than the stock value of sharia trend.

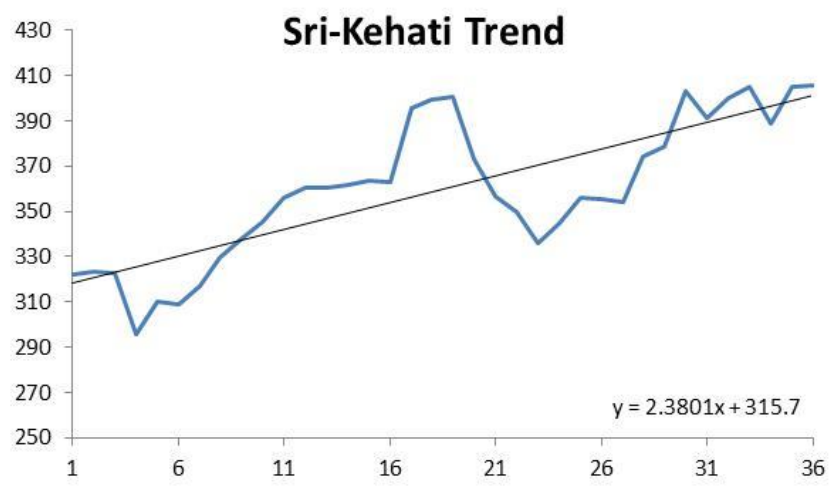

Picture-3. The value of Sri-Kehati Index trend.

Meanwhile, the coefficient of determination between the average values of sharia issuers' shares on the SriKehati index is 0.2646 . This shows that the share value of sharia issuers only contributes $26.46 \%$ to the Sri Kehati index. And the coefficient of determination between the average value of shares of non-sharia issuers to the SriKehati index is 0.8641 . This shows that the share value of non-sharia issuers contributes $86.41 \%$ to the Sri Kehati index. 


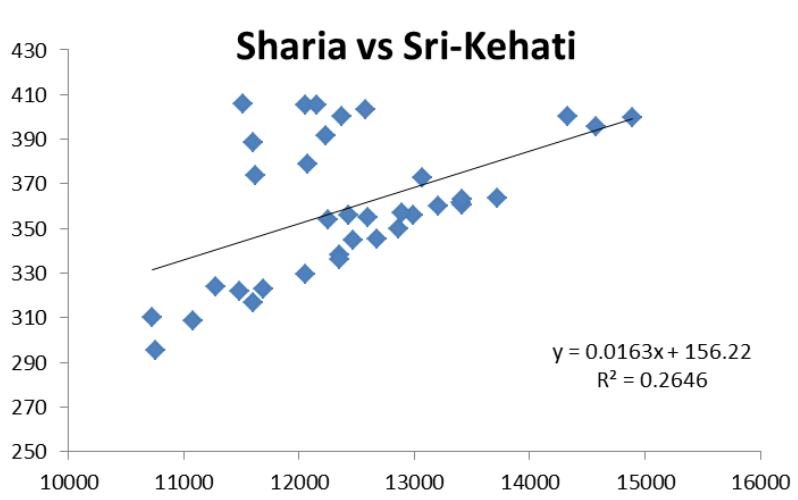

Picture-4. The average value of sharia stocks vs Sri-Kehati Index.

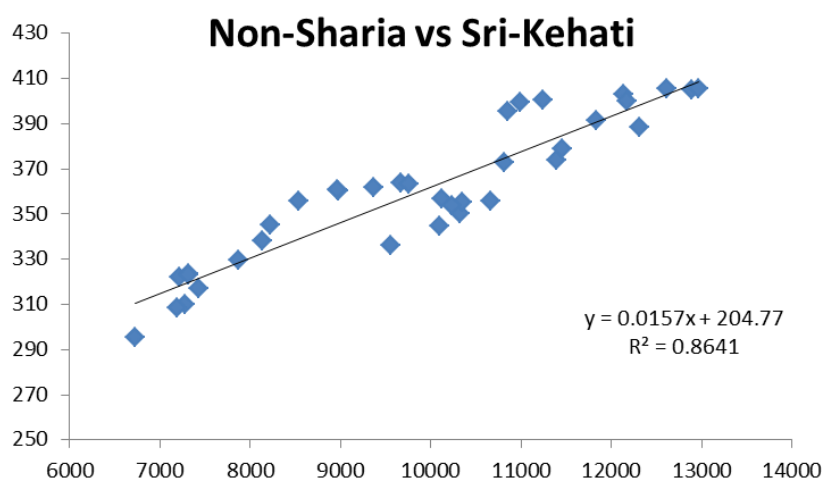

Picture-5. The average value of non-sharia stocks vs Sri-Kehati Index.

Furthermore, through multivariate analysis obtained a regression equation

$\hat{y}=117.187+0.0081 x_{1}+0.014397 x_{2}$.

The multiple linear regression equation above shows that the variable coefficient of the value of sharia stocks is smaller than the coefficient of the variable value of non-sharia stocks. This indicates that the value of non-sharia stocks raises the value of the Sri-Kehati index more than the value of sharia stocks.

This multivariate analysis is in accordance with the bivariate analysis above, namely that the stock value performance of non-sharia issuers is better than sharia issuers. As well as the correlation coefficient and determination of the value of non-Islamic stocks on the Sri-Kehati index is greater than the value of Islamic stocks on the Sri-Kehati index. The relationship between the value of non-Islamic stocks and the Sri-Kehati index is much stronger than the value of Islamic stocks on the Sri-Kehati index.

2. Discussion and conclusion

1. The entire data in this study comes from the activities of the Indonesian stock exchange over a period of 3 years (from August 2016 to July 2019), including: data from 8 sharia issuers that are consistently listed on the JII and Sri-Kehati index, and 4 conventional issuers (conventional banks) consistently listed on the SriKehati index. The rest of the other issuers, both sharia and non-sharia, are not consistently registered with Sri-Kehati. 
2. The results showed that the stock performance of non-sharia companies was better than those of sharia companies. The positive gradient of non-sharia trendline (168.37) is bigger than sharia trendline (11.633). The coefficient of determination between non-sharia stocks and Sri-Kehati index $(86.41 \%)$ is bigger than between sharia stocks and Sri-Kehati index (26.46\%). The multiple linear regression equation is $\hat{y}=117.187+0.0081 x_{1}+0.014397 x_{2}$. This equation shows that the variable coefficient of the value of sharia stocks is smaller than the coefficient of the variable value of non-sharia stocks.

3. The investors prefer to invest in shares in non-sharia companies than in sharia companies. The results also indicate that increasing the qualifications of a sharia company to become a company that applies green innovation technology will not necessarily increase its share value.

4. This fact could also indicate that investors in the Indonesian stock exchange in terms of investing in companies that have implemented green innovation technology have not yet considered whether the companies are sharia or non-sharia.

5. In the future, it needs to be stimulated so that religious and environmentally sound investors can also invest in the Indonesian stock exchange so that the performance of Islamic issuers with environmental insight is better than conventional issuers.

\section{References}

Abbas, J. (2019). Impact of knowledge management practices on green innovation and corporate sustainable development: A structural analysis. Journal of Cleaner Production, 229.

Akbar, M., Iqbal, F., \& Noor, F. (2019). Bayesian analysis of dynamic linkages among gold price, stock prices, exchange rate and interest rate in Pakistan. Resources Policy, 62(June 2017), 154-164. https://doi.org/10.1016/j.resourpol.2019.03.003

Akhtar, F., \& Das, N. (2020). Investor personality and investment performance: from the perspective of psychological traits. Qualitative Research in Financial Markets, 12(3), 333-352. https://doi.org/10.1108/QRFM-11-2018-0116

Akhtar, F., Thyagaraj, K. S., \& Das, N. (2018). The impact of social influence on the relationship between personality traits and perceived investment performance of individual investors: Evidence from Indian stock market. International Journal of Managerial Finance, 14(1), 130-148. https://doi.org/10.1108/IJMF-05-2016-0102

Alam, N., Arshad, S., \& Rizvi, S. A. R. (2016). Do Islamic stock indices perform better than conventional counterparts? An empirical investigation of sectoral efficiency. Review of Financial Economics, 31, 108-114. https://doi.org/10.1016/j.rfe.2016.06.003

Ali, S., Shahzad, S. J. H., Raza, N., \& Al-Yahyaee, K. H. (2018). Stock market efficiency: A comparative analysis of Islamic and conventional stock markets. Physica A: Statistical Mechanics and Its Applications, 503, 139-153. https://doi.org/10.1016/j.physa.2018.02.169

Chen, T. H., Ho, R. J., \& Liu, Y. W. (2019). Investor personality predicts investment performance? A statistics and machine learning model investigation. Computers in Human Behavior, 101, 409-416. https://doi.org/10.1016/j.chb.2018.09.027

Ftiti, Z., \& Hadhri, S. (2019). Can economic policy uncertainty, oil prices, and investor sentiment predict Islamic stock returns? A multi-scale perspective. Pacific Basin Finance Journal, 53, 40-55. 
https://doi.org/10.1016/j.pacfin.2018.09.005

He, X., Huang, S., Chau, K., Shen, H., \& Zhu, Y. (2019). A Study on the Effect of Environmental Regulation on Green Innovation Performance : A Case of Green Manufacturing Enterprises in Pearl River Delta in China. Ekoloji, 28(107), 727-736.

Jawadi, F., Jawadi, N., \& Idi Cheffou, A. (2019). A statistical analysis of uncertainty for conventional and ethical stock indexes. Quarterly Review of Economics and Finance, 74, 9-17. https://doi.org/10.1016/j.qref.2018.03.002

Li, X., Su, C. W., Chang, H. L., \& Ma, J. (2018). Do short-term international capital movements play a role in exchange rate and stock price transmission mechanism in China? International Review of Economics and Finance, 57, 15-25. https://doi.org/10.1016/j.iref.2018.02.010

Lin, W., Cheah, J., Azali, M., Ann, J., \& Yip, N. (2019). Does firm size matter ? Evidence on the impact of the green innovation strategy on corporate fi nancial performance in the automotive sector. Journal of Cleaner Production, 229, 974-988.

Nurhayadi, Y; Rito; Azizah, U. (2018). Model Solusi Efektif Stabilitas Pasar Syariah. Al-Urban: Jurnal Ekonomi Syariah Dan Filantropi Islam, 2(1), 92-106. https://doi.org/10.22236/alurban

Nurhayadi, Y., Heriansyah, D., Susanti, E., \& Azzahra, S. A. (2019). Realita Dinamika Pasar: Studi Intensif Distingsi Syariah Konvensional. Al-Urban: Jurnal Ekonomi Syariah Dan Filantropi Islam, 3(2), 190202. https://doi.org/10.22236/alurban_vol3/is2pp190-202

Nurhayadi, Y., \& Wijiharjono, N. (2018). Strong Correlationsof Sharia Market To Conventional Market: Evidence From Indonesia Stock Exchange. International Journal of Islamic Business and Economics (IJIBEC), 87. https://doi.org/10.28918/ijibec.v1i2.1003

Polzin, F., Sanders, M., \& Stavlöt, U. (2018). Do investors and entrepreneurs match? - Evidence from The Netherlands and Sweden. Technological Forecasting and Social Change, 127(July 2017), 112-126. https://doi.org/10.1016/j.techfore.2017.07.016

Przychodzen, W., Leyva, D. I., \& Hiz, D. (2019). First - mover advantages in green innovation Opportunities and threats for financial performance: A longitudinal analysis. Corporate Social Responsibility and Environmental Management, May, 1-19. https://doi.org/10.1002/csr.1809

Shah, S. Z. A., Ahmad, M., \& Mahmood, F. (2018). Heuristic biases in investment decision-making and perceived market efficiency: A survey at the Pakistan stock exchange. Qualitative Research in Financial Markets, 10(1), 85-110. https://doi.org/10.1108/QRFM-04-2017-0033

Shahzad, M., Qu, Y., Javed, S. A., Zafar, A. U., \& Rehman, S. U. (2020). Relation of environment sustainability to CSR and green innovation: A case of Pakistani manufacturing industry. Journal of Cleaner Production, 253. https://doi.org/10.1016/j.jclepro.2019.119938

Shahzad, M., Qu, Y., Javed, S. A., Zafar, A. U., \& Ur, S. (2019). Relation of Environment Sustainability 
to CSR and Green Innovation: A Case. Journal of Cleaner Production.

Singhal, S., Choudhary, S., \& Biswal, P. C. (2019). Return and volatility linkages among International crude oil price, gold price, exchange rate and stock markets: Evidence from Mexico. Resources Policy, 60(December 2018), 255-261. https://doi.org/10.1016/j.resourpol.2019.01.004

Tang, X., \& Yao, X. (2018). Do financial structures affect exchange rate and stock price interaction? Evidence from emerging markets. Emerging Markets Review, 34, 64-76. https://doi.org/10.1016/j.ememar.2017.10.004

Varadarajan, R. (2017). Innovating for sustainability: a framework for sustainable innovations and a model of sustainable innovations orientation. Journal of the Academy of Marketing Science, 45(1), 14-36. https://doi.org/10.1007/s11747-015-0461-6

Walpole, Ronald E; Myers, Raymodh H; Myers, Sharon L; Ye, K. (2013). Essentials of Probability \& Statistics for Engineers and Scientists. Pearson.

Xue, M., \& Boadu, F. (2019). The Penetration of Green Innovation on Firm Performance: Effects of Absorptive Capacity and Managerial Environmental Concern. Sustainability.

Ye, Q., \& Cheng, C. (2019). Green Technological Innovation Efficiency and Financial Ecological Environment. Open Journal of Social Science, 7, 132-151. https://doi.org/10.4236/jss.2019.712011

Zhang, D., Rong, Z., \& Ji, Q. (2019). Green innovation and firm performance: Evidence from listed companies in China. Resources, Conservation \& Recycling, 144(January), 48-55. https://doi.org/10.1016/j.resconrec.2019.01.023 